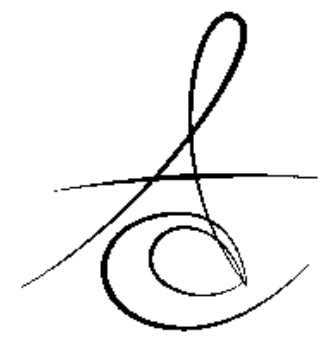

\title{
ÇÜRÜK RİSKİ VE GENETİK
}

\author{
CARIES RISK AND GENETIC
}

Makale Kodu/Article code: 3151

Makale Gönderilme tarihi: 24.11.2016

Kabul Tarihi: 02.02.2017

\section{öz}

Multifaktöriyel bir hastalık olan diş çürüğünün etiyolojisi yıllardır araştırılmaktadır. Aynı çevresel risk faktörlerine maruz kalan bireylerin çürük riskinin aynı olmadığı belirlenmiş ve bu sonuç çürüğün etiyolojisinde genetik faktörlerin de rol oynadığını akla getirmiştir. Diş çürükleri toplumun tamamında görüldüğü için geçmişte, genetik faktörlerin diş çürüğünün etiyolojisi üzerindeki etkisi önemsenmemiştir. Son on yılda bireylerin çürük riskine etki eden genetik faktörler ile ilişkili çalışmalarda artış gözlenmiştir. Diş çürüğü üzerine yapılan genetik araştırmalar 1930'lu yıllarda deneysel hayvan çalışmaları ve gözlemsel araştırmalar olarak başlamıştır. İnsanlar üzerindeki gen polimorfizmini inceleyen çalışmalar ancak son yıllarda karşımıza çıkmaktadır. İncelenen genler çürük riskiyle ilişkisine göre spesifik kategorilerde gruplandırımaktadır. Günümüzde incelenen başlıca gen kategorileri mineralizasyon, ağız içi savunma elemanları, tükürük proteinleri, tat alma ve beslenme tercihleri ile ilgili genetik çalışmaları içermektedir. Çürüğün karmaşık karakterli bir hastalık olması, birçok biyolojik ve çevresel faktörlerden etkilenmesi ve çürük ile ilişkili genetik araştırmaların yetersiz olması nedeniyle daha fazla sayıda genetik temelli çalışmalara intiyaç duyulmaktadır. Bu derlemenin amacı, diş çürüğü ile ilişkili mevcut genetik çalışmalar ve gen polimorfizmleri hakkında kısa bir bilgilendirme sağlamaktır.

Anahtar Kelimeler: Diş çürüğü, genetik polimorfizm, genetik araştırmalar

\section{ABSTRACT}

Dental caries is a multifactorial disease and the etiology of caries has been studied for many years. However when exposed to the same levels of environmental risk factors, some patients may be more susceptible or resistant to caries than others. Those differences may be due to genetic factors in the etiopathogenesis of dental caries. In the past, the importance of genetic factors was disregarded mainly because the dental caries was present in almost the entire population. The last decade has seen a steep increase in research related to genetic factors influencing individuals' caries risk. Genetic research applied to dental caries began in the 1930s with experimental reports in animals and human observational research. Only recently, have some studies begun to search for gene polymorphisms in humans. These genes can be grouped in specific categories, based on the factor influencing dental caries. The major candidate gene categories to date include; enamel formation genes, immune response genes, genes related to saliva and genes related to taste and dietary habits. Due to the complex characteristics of the disease, the strong influence from several biological and environmental factors, and the small number of genetic studies related to dental caries, the genetic basis still requires further study. The aim of this review is to provide a brief description of the current genetic studies and gene polymorphisms related to dental caries.

Key words: Dental caries, genetic polymorphism, genetic research

*Recep Tayyip Erdoğan Üniversitesi, Diş Hekimliği Fakültesi, Restoratif Diş Tedavisi AD, Rize
${ }^{* *}$ Süleyman Demirel Üniversitesi, Diş Hekimliği Fakültesi, Restoratif Diş Tedavisi AD, Isparta 


\section{GİRİŞ}

Diş çürüğü etiyolojisinde yer alan dört temel faktör olan, biyofilm, diyet, zaman ve konak, etkileşiminin bir sonucu olarak meydana gelmektedir. ${ }^{1,2}$ Daha sonraki yıllarda yapılan çalışmalar ile diş çürüğünün oluşumuna neden olan ve çürüğe yatkınlığı artıran daha fazla risk faktörü belirlenmiştir. ${ }^{2}$ Dolayısıyla diş çürüğü; içerisinde biyolojik, sosyal, davranışsal ve psikolojik bileşenlerin bulunduğu çevresel ve genetik faktörlerin etkileşimi sonucu oluşan multifaktöriyel bir hastalık olarak tanımlanmaktadır. ${ }^{3}$

Günümüze kadar araştırmacılar birçok çevresel faktörü tek başına veya birlikte ele alarak çürük riskini değerlendirmişlerdir. ${ }^{4-11}$ Bunun yanında sadece çevresel faktörlerin değerlendirilmesinin diş çürüğünün oluşumunu açıklamadığının altı çizilmiştir. Çünkü aynı çevresel risk faktörlerine maruz kalan bireylerin çürük riskinin aynı olmadığı belirlenmiş ve bu sonuç çürüğün etiyolojisinde genetik faktörlerin de rol oynadığını akla getirmiştir. $^{2}$ Diş çürükleri toplumun tamamında görüldüğü için geçmişte, genetik faktörlerin diş çürüğünün etiyolojisi üzerindeki etkisi önemsenmemiştir. Çürük ve genetik arasındaki ilişki, kalıtımsal özelliklerle açıklanmaya çalışıımış ve diş çürüğü ile ilişkilendirilen bu kalıtımsal faktörlerin dişin yapısal kompozisyonu, diş morfolojisi, ark formu gibi bazı özellikler üzerinde etkili olduğu belirlenmiştir. 3,12

Diş çürüğü ve genetik arasındaki ilişkinin değerlendirilmesi yakın zamanda gerçekleşen gelişmelerle başlamaktadır. Hastalıkların etiyolojisinde rol oynayan ve hastalıklar için risk oluşturabilecek genler hakkında yararlı bilgiler, insan DNA'sındaki üç milyar baz çiftinin dizilimini ortaya çıkaran 'İnsan Genom Projesi'nin 2003 yılında tamamlanmasının ardından elde edilmiştir. ${ }^{13} \mathrm{Bu}$ gelişmenin ışı̆̆ında 2008 yılında çürükle ilişkili genomik bölgelerin tespiti için yapılan genom taraması sonucu, düşük ve yüksek çürük yatkınlığıyla ilgili olan gen bölgeleri tespit edilmiştir. ${ }^{2,14}$ Diş çürüğünde genetiğin rolünün anlaşılması için yapılan ikiz çalışmalarıyla çürüğün oluşumunda genetiğin rolünün tek başına \%35-55 oranında olabileceği ifade edilmiştir. ${ }^{15}$ Günümüze kadar mine ve dentin mineralizasyonu, tükürük proteinleri, ağız içi savunma elemanları, tat alma ve beslenme tercihleri ile ilgili gen polimorfizmleri ve çürük arasındaki ilişki incelenerek genetik faktörlerin çürük riski üzerindeki rolü araştırılmıştır. ${ }^{2,16}$

\section{Genetik Çalışmalar}

Genetik temelli multifaktöriyel hastalıkların anlaşılmasının zor olmasından dolayı araştırmacılar gene- tik temelli hastalıkları tanımlamak ve değerlendirmek için birçok farklı çalışma yapmaktadır. ${ }^{17}$ Diş çürüklerinin genetik temelinin anlaşılması için günümüze kadar yapılan çalışmalar aşağıdaki gibi sınıflandırılabilir: ${ }^{2}$

A. Bakteri genetiğinin araştırılması

B. Konak genetiğinin araştırılması

1. Deneysel hayvan çalışmaları

2. Gözlemsel araştırmalar

a. Ailesel yığılım araştırmaları

b. İkiz çalışmaları

3. Bağlantı ve ilişki analizleri

a. Hayvan çalışmaları

b. İnsan çalışmaları (Gen polimorfizmi ve gen ekspresyonu çalışmaları)

- Mineralizasyon ile ilişkili çalışmalar

- Tükürük proteinleri ile ilişkili çalışmalar

- Bağışıklık ile ilişkili çalışmalar

- Tat alma ile ilişkili çalışmalar

\section{A. Bakteri Genetiğinin Araştırılması}

Çürüğün genetik yönlerini araştıran 1970 ile 1990 yılları arasındaki çalışmaların büyük çoğunluğu karyojenik bakterilerin gen varyantları üzerinde durmaktadır. ${ }^{2}$ Bu çalışmalarla, karyojenik bakterilerin genetik yapılarının deşifre edilmesiyle bakterilerin diş çürüklerine neden olan metabolizmalarının aydınlatılması, yeni ve etkin tedavilerin uygulanması amaçlanmaktadır. ${ }^{18}$ Çalışmalarda mutans streptokok ve çürüğe yatkınlıkla ilişkili diğer suşları araştırımış ve birçok Streptococcus mutans türlerinin diş çürüğünü etkilediği belirtilmiştir. $^{2}$

\section{B. Konak Genetiğinin Araştırılması \\ 1. Deneysel Hayvan Çalışmaları}

Farklı fare suşları ile yapılan çalışmalar çürüğe yatkınlıktaki farklılığın genetik faktörler nedeniyle olabileceği hipotezini desteklemektedir. Genetik olarak heterojen yapıdaki farelerin aynı çevre koşullarında çürüğe farklı yatkınlık ve direnç gösterdiği belirtilmektedir. Ayrıca fareler üzerinde yapılmış araştırmalarda farelerdeki 2, 8 ve 17. kromozomun diş çürüğü ile bağlantılı olduğu saptanmıştır. ${ }^{2}$

\section{Gözlemsel Araştırmalar \\ a. Ailesel yığılım araştırmaları}

Ailesel yığılım çalışmaları hastalığın genetik bağlantısını tanımlamak için ilk adım olarak belirtilmektedir. ${ }^{17}$ Diş çürüğünün ailesel yığılımını inceleyen çalışmalar ilk olarak 1938 yılında başlamıştır. Bu çalışmada geçmiş çürük deneyimine göre hiç çürüğü bulunmayan ve geçmiş çürük deneyimi yüksek olan

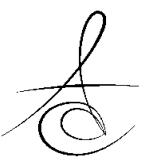


çocukların kardeşleri incelenmiştir. Buna göre çürüksüz çocukların kardeşlerinde, yüksek çürüklü çocukların kardeşlerine göre daha düşük oranda çürük gözlendiği ifade edilmiştir. Bu yönde yapılan diğer bir çalışmada, dişleri bulunan ve hiç dişi bulunmayan annelerin çocukları karşılaştırmış sonuçta hiç dişi bulunmayan annelerin çocuklarının süt ve kalıcı dişlerinde daha fazla çürük saptandığı belirtilmiştir. ${ }^{2}$

\section{b. İkiz çalışmaları}

Tek yumurta ikizleri birbirleriyle aynı genetik özellikleri göstermektedir. Bu nedenle ikizler bir genetik hastalığın çevresel faktörlerden ne kadar etkilendiğini araştırmak için mükemmel bir olanak sunmaktadır. Çift yumurta ikizleri ise genetik olarak birbirlerine $\% 50$ oranında benzerlik göstermektedir. Tek yumurta ikizlerinde görülen hastalıklardaki farklılıklar tamamen çevresel faktörlerden kaynaklanırken çift yumurta ikizleri arasındaki hastalık farklılıkları çevresel ve genetik farklılıkların birleşiminden kaynaklanmaktadır. İkiz çalışmalarından elde edilen sonuçlar bir fenotipe genotipin ne oranda etki ettiğini hesaplamakta kullanılabilmektedir. ${ }^{17}$ Günümüze kadar çürüğün genetik temelini araştıran çok sayıda ikiz çalışması yapıımıştır. Bununla ilgili olarak, tek yumurta ikizle- rinde çürük oluşum insidansının çift yumurta ikizlerine göre daha yüksek olduğu bildirilmektedir. Ayrıca ikiz çalışmalarıyla çürükteki genetiğin rolünün $\% 70$ oranında olduğu ifade edilmektedir. $^{2}$

\section{Bağlantı ve İlişki Analizlerì}

Bağlantı analizlerinin amacı bir hastalıktan sorumlu olduğu bilinen bir genin kromozom üzerindeki yerini tespit etmektir. ${ }^{17}$ Bağlantı analizi ile aynı kromozom üzerinde birbirine yakın yerleşmiş iki bölgenin anne ve babadan çocuğa aktarılırken bir arada geçiş olasılığı hesaplanmaktadır. ${ }^{19}$ Analiz genellikle mutant gen adı verilen hastalığın oluşumuna sebep olan gen ve polimorfizm ile tespit edilen genetik markör arasında ilişki kurmaktadır. ${ }^{17}$

\section{a. Hayvan çalışmaları}

Hayvan modelleri kullanılarak gerçekleştirilen genetik araştırmaların amacı çürüğe yatkınlık veya çürüğe karşı direnç ile ilişkili polimorfizmlerin araştırılması, bunun yanında çürükle ilişkili genlerin ve genomik bölgelerin tespit edilmesidir. ${ }^{2} \mathrm{Bu}$ konuda yapılan bir çalışmada farelerde çürük ile ilişkili olarak, bağışıkta rol oynayan büyük doku uygunluk kompleksi (MHC) haplotipinin 2., 8. ve 17. kromozomlarda yer aldığı tespit edilmiştir. Bağışık yanıtın çürük gelişimini etkileyebileceği hipotezinden yola çıkılarak yapılmış başka bir çalışmada ise, sistemik olarak lenf nodlarının şişmesine neden olan lenfoproliferatif genin çıkarıldığı nokaut adı verilen farelerde daha yüksek oranda çürük oluşumunun gözlendiği belirtilmektedir. ${ }^{2}$

\section{b. İnsan çalışmaları (Gen polimorfizmi ve gen ekspresyonu çalışmaları)}

Çürükteki multifaktöriyel kalıtımın rolü 1970'lerden günümüze kadar tartışılmaktadır. Muhleman adlı araştırıcı 1972 yılında bazı genlerin mine yüzeyini etkilediğini diğer bir grup genin tükürük kompozisyonu ile ilişkili olduğunu ve bazı genlerin ise enfeksiyona karşı bağışık yanıtın oluşmasında görev aldığını ileri sürmüştür. ${ }^{20}$ Buna rağmen insanlarda çürükle ilişkili genomik bölgelerin tespiti için gen polimorfizmleri ve ekspresyonları ile ilgili çalışmalar yakın geçmişte

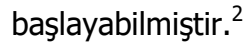

Diş çürükleri ile ilgili ilk bağlantı analiz çalışması 2008 yılında gerçekleştirilmiştir. Çürükle ilişkili genomik bölgelerin tespiti için yapılan genom taraması sonucu düşük çürük yatkınlığıyla ilgili üç adet (5q13.3, 14q11.2, ve Xq27.1), yüksek çürük yatkınlığıyla ilgili iki adet (13q31.1 ve 14q24.3) lokus tespit edilmiştir. Söz konusu genlerin tükürük akış hızı, beslenme tercihi ve bağışıklık sistemi ile ilgili olabileceğinin altı çizilmiştir. ${ }^{2,14}$ Bu çalışmanın devamı niteliğinde son yıllara ait bir araştırmada 14q11.2 lokusuna ait bağışık yanıtın oluşmasında görev alan TRAV4 gen ekspresyonu incelenmiştir. Sonuçta TRAV4 geninin çürükten korunmada rol oynayabileceği bildirilmektedir. ${ }^{21}$

Hayvan modelleri kullanılarak diş çürüklerinin polimorfizm ile ilişkilendirildiği çalışmalar 1980'li yıllarda başlasa da insanlar üzerindeki ilk çalışma 2005 yılında yayınlanmıştır. ${ }^{2,22}$ Günümüze kadar çürük ile arasındaki ilişkinin araştırıldığı genetik çalışmalar; mineralizasyon, tükürük proteinleri, bağışıklık sistemi ve tat alma ile ilgilidir.

\section{Mineralizasyon ile ilişkili çalışmalar}

Mine formasyonunun genetik olarak kontrol edilmesi dolayısıyla diş boyutu, diş morfolojisi ve dişin çürüğe yatkınlığı bireyin kalıtımsal özelliklerinden etkilenmektedir. ${ }^{15} \mathrm{Bu}$ nedenle mine formasyonunda görev alan proteinleri kodlayan genler ile çürüğe yatkınlık arasında ilişki olabileceği belirtilmektedir. ${ }^{14,22-25}$ Günümüze kadar çürükle ilişkisi araştırılan amelogenin, enamelin, tuftelin, ameloblastin ve kallikrein proteinleri minenin mineralizasyonunda, sialofosfoprotein ise dentinin mineralizasyonunda rol oynamaktadır. $9,10,22-24,26,27$

Minenin organik matriksinin \%90'ını prolinden zengin protein olan amelogenin oluşturmaktadır. ${ }^{15,27}$ Minenin gelişimi sırasındaki mineralizasyona katılan amelogenin proteini AMELX geni tarafından kodlan-

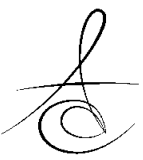


maktadır. ${ }^{24,28,29} \mathrm{Bu}$ nedenle amelogenin proteininin mine dokusunun oluşumu için önemli olduğu ifade edilmektedir. Ayrıca bu proteindeki normalin dışındaki genetik değişiklikler minenin yapısını değiştirerek mineral kaybına ve mine yüzeyinde biyofilm tabakasının artışına sebep olabilmektedir. ${ }^{23}$ Mineralizasyonda etkili diğer bir protein olan enamelin olgunlaşmış organik matrikste bulunmakta ve mine formasyonunda görev almaktadır. ${ }^{27}$ Enamelin proteini ENAM geni tarafından kodlanmaktadır. ${ }^{22-24}$ Mineralizasyonunun başlamasında rol oynayan tuftelin proteinini ise TUFT1 geni tarafından kodlanmaktadır. Diğer bir protein olan ameloblastin diş gelişimi sırasında mine kristallerinin uzamasını kontrol etmektedir. Ameloblastin proteini AMBN geni tarafından kodlanmaktadır. Minenin maturasyonundan sonraki mine tabakasının oluşmasında matriks minerallerinin düzenli yerleşimini kolaylaştıran protein kallikreindir. Bu protein KLK4 geni tarafından kodlanmaktadır.22,27

Diş çürüğü ve AMELX, AMBN, TUFT1, TFIP11 ve KLK4 gen polimorfizmleri arasındaki ilişkinin araştırıldığı 3-5 yaşlarındaki çocuklarda çürük ve incelenen genler arasında ilişkinin bulunmadığı ifade edilmektedir. Ayrıca TUFT1- $T$ alelinin çürük oluşumuna mutans streptokok kolonizasyonu ile birlikte neden olabileceği vurgulanmaktadır. ${ }^{22,27}$ Benzer şekilde, 20-60 yaş aralığındaki erişkinler üzerinde yapılan başka bir çalışmada da AMELX gen polimorfizminin çürük riski ile ilişkili olmadığı sonucuna ulaşılmıştır. ${ }^{9} \mathrm{Bu}$ sonuçların aksine aynı genlerin kullanıldığı farklı yaş grupları üzerinde gerçekleştirilen çalışmalarda AMELX, AMBN ve TUFT1 polimorfizmleri çürükle ilişkili bulunmaktadır. ${ }^{22-24}$ Ayrıca ENAM genindeki polimorfizm mutans streptokok varlığında çürükle ilişkili olabilmektedir. ${ }^{15,23}$ Çürüğe karşı duyarlııkta AMELX alelinin erkeklerde AMELY tarafından kompanse edilmesi erkeklerin kadınlara göre daha az çürük hassasiyeti göstermesini açıklamaktadır. $^{15,21}$

Matriksmetalloproteinaz minenin oluşumu esnasında hücre matriks etkileşiminin düzenlenmesi ve dokuların yeniden şekillenmesi işleminde rol almaktadır. Matriksmetalloproteinazlar MMP geni tarafından kodlanmaktadır. ${ }^{22-24,26,27}$ Kötü ağız hijyenine sahip çocuklarda MMP20 genindeki varyasyonlar, geçmiş çürük deneyimi ile ilişkili olabilmektedir. ${ }^{30}$

Dentinin mineralizasyonunda görev alan fosfoprotein ve dentinde bulunan sialoproteinin birleşmesi sonrasında oluşan dentinsialofosfoproteini kodlayan gen DSPP ile diş çürüğü arasında ilişki olabileceği ifade edilmektedir. ${ }^{31}$

\section{Tükürük proteinleri ile ilişkili çalışmalar}

Tükürük proteinlerini kodlayan genler ile çürüğe yatkınlık arasında ilişki olabileceği bildirilmektedir. Günümüze kadar tükürük proteinlerinden karbonik anhidraz 6, prolinden zengin protein, müsin ve aquaporini kodlayan genlerin çürükle ilişkisi araştırılmıştır. ${ }^{9,26,32-35}$

Karbonik anhidraz 6, tükürük ve diğer vücut sıvılarında bulunan karbonik anhidraz enziminin salgı formudur. Bu enzim ilk defa parotis ve submandibular bezlerin seröz hücreleri tarafından üretilen tükürük içinde tanımlanmıştır. Tükürükteki karbonik anhidraz 6'nın dental plağa penetre olarak tükürük bikarbonatı ile asit nötralizasyonunu kolaylaştırdığı ifade edilmektedir. Bikarbonat sistemi tükürüğün tamponlama kapasitesine katkıda bulunan ana tampondur. Bikarbonat iyonlarının plak bakterileri tarafından üretilen laktik ve asetik asitinötr hale getirerek bu şekilde demineralizasyonu azalttığı bildirilmektedir. ${ }^{33,36}$ Karbonik anhidraz 6, CA6 geni tarafından kodlanmaktadır. Diş çürüğü ve CA6 gen polimorfizmi arasında ilişki bulunmamasına rağmen, tükürük tamponlama kapasitesi CA6 genindeki polimorfizmden etkilenebilmektedir. . $^{93}$

Tükürük protein kompleksi adı verilen genler tarafından kodlanan prolinden zengin proteinler tükürük proteinlerinin \%37'sini oluşturmaktadır. Prolinden zengin proteinler mutans streptokok türü bakterilerin diş yüzeyinde koloni oluşturarak biyofilm tabakasını meydana getirmelerini kolaylaştırmaktadır. ${ }^{15,37}$ Dolayısıyla çürüğe yatkınlık ve mutans streptokok kolonizasyonu arasındaki ilişki büyük oranda genetik varyasyon ile açıklanmaktadır. Bireylerlerin farklı geçmiş çürük deneyimine sahip olmasına sebep olan tükürükteki polimorfik, asidik prolinden zengin proteinler $\mathrm{PRH} 1$ ve $\mathrm{PRH} 2$ genleri tarafından kodlanmaktadır. ${ }^{15}$ Beyaz ırkta PRH1 genine ait Db alelinin bulunmaması çürük oranlarını artırmıştır. ${ }^{37}$ Ayrıca $\mathrm{Pa}$ ve Pr22 genotipine sahip olmak, daimi dişlerde çürük oluşma riskini yükseltmektedir. ${ }^{15}$

Tükürük savunma elemanları ağız sağlığının sürdürülmesi ve çürükten korunmada önemli rol oynamaktadır. Tükürük salgısı içinde bulunan antimikrobiyal peptidler (AMP) mikroorganizmaların geniş spektrumlarına karşı ilk savunma hattını oluşturan doğal antibiyotiklerdir. Bu peptidlerin önemi özellikle mikrobiyal floranın sürekli hakim olduğu ağız içinde öne çıkmaktadır. ${ }^{15}$ Yapısal özelliklerine göre antimikrobiyal peptidleri defensinler, histatinler ve katelisidinler olarak sınıflandırmak mümkündür. ${ }^{15,38}$ Alfa defensinler gru- 
bunda yer alan insan nötrofil peptidlerinin (HNP1-3) tükürük içindeki seviyeleri genetik olarak kontrol edilmektedir. Bu seviyenin düşük olması, çocuklarda çürük riskini değerlendirmek için kullanışlı bir veri olarak sayılabilmektedir. ${ }^{15}$

Tükürük bileşenleri ile çürük oluşumunun ilişkisine yönelik incelenen başka bir tükürük proteini ise müsindir. Müsin proteininin en önemli görevi diş yüzeyine bakterilerin kolonizasyonunu engellemesidir. Yapılan çalışmalarda çürük oluşumu ile müsin proteinini kodlayan MUC7 geni arasında bir ilişki bulunamamıştır. ${ }^{32}$

Tükürükte bulunan aquaporin proteinleri diş gelişiminde ekstrasellülermatriksin su alımı sırasında rol oynamaktadır. Aquaporin 5 proteini AQP5 geni tarafından kodlanmakta ve tükürük salgısında görev almaktadır. Farelerde AQP5 eksikliği tükürük akışını azaltarak çürüğe yatkınlıkla ilişkilendirilmiş, insanlarda ise bu gendeki çürüğe karşı koruyucu özellik taşıyan aleler tespit edilmiştir. ${ }^{26}$

\section{Bağışıklık ile ilişskili çalışmalar}

Diş çürüğünün enfeksiyöz bir hastalık olması sebebiyle insanların bağışıklık sistemlerini kontrol eden genler ve çürük arasındaki ilişkinin araştırıması önemlidir. ${ }^{39}$ Ağız içi dokularında ve diğer organlarda bağışık sisteminin temel unsurları olarak bulunan beta defensinler konağın enfeksiyöz patojenlere karşı ilk savunmasında rol alan antimikrobiyal etkili peptidlerdir. ${ }^{39,40}$ Dişeti oluğu sIviSı ve tükürükten salgılanan beta defensin 1 (DEFB1) proteinine ait gen aktarımındaki değişiklikler periodontal hastalığa ve diş çürüğüne neden olabilmektedir. ${ }^{39}$ Diş çürüğü ve DEFB1 gen polimorfizmi arasında anlamlı ilişki tespit edilmesi dolayısıyla araştırmacılar, söz konusu polimorfizmin çürük riskinin klinik göstergesi olarak sayılabileceğini ifade etmektedir. ${ }^{9,39}$

Bağışık yanıtın oluşmasında önemli rol oynayan büyük doku uygunluk kompleksi (MHC) insan lökosit antijeni (HLA) olarak da adlandırımaktadır. ${ }^{15} \mathrm{Bu}$ moleküllerdeki değişikliklerin mikroorganizmalara karşı farkı bağışık yanıta sebep olarak çürüğe yatkınlığı artırabildiği bildirilmektedir. Ayrıca mutans streptokok seviyesinin MHC molekül geni tarafından kontrol edildiğine dair çalışmalar mevcuttur. ${ }^{15,41}$

Bağışıkık ile ilişkili genler ile çürük oluşumunun ilişkisine yönelik incelenen diğer savunma elemanları, erken çocukluk döneminde önemli rol oynayan mannoz-bağlayıcı lektin (MBL) ve bakteri ligandı (CD14) gen polimorfizmleridir. Diş çürüğü ve MBL gen polimorfizmi arasında ilişki gözlenmezken, bakteri ligandı CD14 genindeki CD14-260:TT genotipi, çürüğün neden olduğu abse veya fistül oluşumunda koruyucu rol oynamaktadır. 42,43

\section{Tat alma ile ilişkili çalışmalar}

Beslenmenin diş çürüğü patojenitesinde rol oynadığı ve şeker tüketiminin bireylerin önemli ölçüde genetik olarak kontrol edilen tat tercihlerinden etkilendiği bildirilmektedir. ${ }^{44}$ Günümüze kadar çürük ve tat alma ilişkisine yönelik incelenen gen polimorfizmleri, guanin nükleotid bağlayıcı protein (G proteini) ve tat reseptör genlerine aittir. ${ }^{45,46}$ Guanin nükleotid bağlayıcı protein GNAT3 geni tarafından kodlanarak tat reseptörlerinden gelen sinyali tat tomurcuklarına iletmektedir. Tat reseptörlerinden olan 'tip 1, 2. üyesi' TAS1R2 geni tarafindan kontrol edilmektedir. Bu reseptör tatı tadını algılamaktadır. ${ }^{45}$ Tat reseptörlerinden 'tip 2, 38. üyesi' ise TAS2R38 geni tarafından kodlanmakta ve acı tadını algılamaktadır. Buna ek olarak TAS2R38 genindeki değişiklikler bireyleri fenotipik üç gruba ayırmaktadır. Bu gruplar; süper tadıcılar, orta seviyedeki tadıcılar ve tat almayanlar olarak sıralanmaktadır. Bireyler arası acı tadının algılanmasındaki fenotipik farklııkların TAS2R38 geni tarafından kontrol edilen acı duyusunun propiltiurasil (PROP) ve feniltiokabamid (PTC) gibi acı tadıyla kimyasal olarak ilişkili bileşiklerin farklı algılanması sonucunda meydana geldiği bildirilmektedir. ${ }^{46}$ Bireylerin tat profillerini ölçmek için PROP şeritleri kullanılabilmektedir. Bu şerit dil yüzeyine bastırıldığında süper tadıı birey tat almayan bireye kıyasla tadı çok acı olarak algılamaktadı. ${ }^{47}$ Süper tadıcı bir bireyin, tat almayan bireye göre dilin ön bölgesinde daha çok tat tomurcuğuna sahip olduğu, acı ve şeker gibi tatları daha fazla algıladığı bildirilmektedir. ${ }^{46,47}$ Bu yönde yapılan bir çalışmada süper tadıcı bireylerin daha az şekerli yiyecek sevdiği ve geçmiş çürük deneyiminin tat almayan bireylere göre anlamlı derecede yüksek olduğu saptanmıştır. ${ }^{47}$

Tat alma ile ilişkili genlerindeki polimorfizmler değerlendirildiğinde TAS2R38 ve TAS1R2 polimorfizmlerinin çürük riskiyle ilişkili olduğu bildirilmektedir. ${ }^{9,45,46}$

\section{SONUÇ}

Moleküler genetik bilimindeki gelişmeler diş çürüğünün tedavisinde ve çürükten korunmada yeni stratejileri ortaya çıkarmaktadır. Gelecekte diş fırçalama sıklı̆ı veya diyet alışkanlığı gibi çevresel risk faktörleri aynı olan hastalara çürük risklerinin neden farklı olduğu, genetik risk faktörleriyle açıklayabilecek- 
tir. Diş çürüğü patogenezinin aydınlatılması üzerinden 100 yıl geçmiş olmasına rağmen çürük prevelansı hala çok yüksektir. Yapılan çalışmalarda yüksek çürük riskli bireylerin tespiti ve tedavi edimesi için bireysel moleküler biyomarkırların kullanılması teşvik edilmektedir. Gelecekte yapılacak olan çalış- malarda yeni genetik faktörlerin ve çürük riskiyle ilişkili genomik bölgelerin tespit edilmesi, çürük etiyolojisinin daha iyi anlaşılmasını sağlayacaktır. Böylece ileride moleküler aşı ve hatta gen terapisi gibi koruyucu ve terapötik amaçlı yeni yöntemlerin geliştirilmesi olanaklı hale dönüşecektir.

Gül Yıldız Telatar: ORCID ID: 0000-0001-5137-9282

R.Banu Ermiş: ORCID ID: 0000-0001-5497-5100

\section{KAYNAKLAR}

1. Evans R, Lo E, Darwell B. Determinants of Variation in Dental Caries Experience in Primary Teeth of Hong Kong Children Aged 6-8 Years. Community Dent Oral Epidemiol 1993;21:1-3.

2. Werneck RI, Mira MT, Trevilatto PC. A Critical Review: An Overview of Genetic Influence on Dental Caries. Oral Dis 2010;16:613-23.

3. Zero DT. Dental Caries Process. Dent Clin North Am 1999;43:635-64.

4. Al Mulla AH, Kharsa SA, Kjellberg $H$, Birkhed D. Caries Risk Profiles in Orthodontic Patients at Follow-up Using Cariogram. Angle Orthod 2009;79:323-30.

5. Drake CW, Hunt RJ, Beck JD, Koch GG. Eighteenmonth Coronal Caries Incidence in North Carolina Older Adults. J Public Health Dent 1994;54:24-30.

6. Joshi A, Papas AS, Giunta J. Root Caries Incidence and Associated Risk Factors in Middle-aged and Older Adults. Gerodontology 1993;10:83-9.

7. MacEntee MI, Clark DC, Glick N. Predictors of Caries in Old Age. Gerodontology 1993;10:90-7.

8. Ruiz Miravet A, Montiel Company JM, Almerich Silla JM. Evaluation of Caries Risk in a Young Adult Population. Med Oral Patol Oral Cir Bucal 2007;12: 412-18.

9.Yildiz G, Ermis RB, Calapoglu NS, Celik EU, Türel GY. Gene-Environment Interactions in the Etiology of Dental Caries. J Dent Res 2016;95:74-9.

10.Yıldız G, Ermiş RB. AMELX Gen Polimorfizminin Cinsiyet ve Çürük Riski Açısından Değerlendirilmesi. Acta Odontol Turc (Basımda).

11.Yıldız G. AMELX, CA6, DEFB1 ve TAS2R38 Gen Polimorfizminin ve Gen-Çevre Etkileşiminin Erişkinlerdeki Çürük Etiyolojisi ve Risk Değerlendirmesi
Üzerindeki Etkilerinin Araştırılması. Doktora tezi, Süleyman Demirel Üniversitesi, 2014.

12. Selwitz RH, Ismail AI, Pitts NB. Dental caries. Lancet 2007; 369: 51-9.

13. Shuler C. Inherite Risks for Susceptibility to Dental Caries. J Dent Educ 2001;65:1038-45.

14. Vieira AR, Marazita ML, Goldstein-McHenry $T$. Genome-wide Scan Finds Suggestive Caries Loci. J Dent Res 2008;87:435-9.

15. Renuka P, Pushpanjali K, Sangeetha R. Review on "Influence of host genes on dental caries" J Med Dent Sci 2013;4:86-92.

16. Vieira AR, Modesto A, Marazita ML.Caries: Review of Human Genetics Research. Caries Res 2014;48:491-506.

17. Pal GP, Mahato NK. Genetics in Dentistry. 2010 1st ed., New Delhi, India: Jaypee, 2010.

18. Ulucan $K$, Pul U, Akçay $T$. Diş Çürüklerinin Oluşumuna Moleküler Yaklaşım. Journal of Cell Mol Biol 2010;8:35-9.

19. Boyacıoğlu SÖ, Dündar M. Gen Haritalama Stratejileri. Sağlık Bilimleri Dergisi J Health Sci 2012;21:50-60.

20. Muhlemann $H$. Karies und Parodontopathien beim. Menschen in genetischer Sicht. Schweiz Monatsschr Zahnheilk 1972;82:942-59.

21. Briseño-Ruiz J, Shimizu T, Deeley K, Dizak PM, Ruff TD, Faraco IM Jr, Poletta FA, Brancher JA, Pecharki GD, Küchler EC, Tannure PN, Lips A, Vieira TC, Patir A, Koruyucu M, Mereb JC, Resick JM, Brandon CA, Letra A, Silva RM, Cooper ME, Seymen F, Costa MC, Granjeiro JM, Trevilatto PC, Orioli IM, Castilla EE, Marazita ML, Vieira AR. Role of TRAV Locus in Low Caries Experience. Hum Genet 2013;132:1015-25.

22. Slayton RL, Cooper ME, Marazita ML. Tuftelin, Mutans Streptococci, and Dental Caries Susceptibility. J Dent Res 2005;84: 711-14.

23. Patir A, Seymen F, Yildirim M, Deeley K, Cooper $M E$, Marazita ML, Vieira AR. Enamel Formation Genes are Associated with High Caries Experience in Turkish Children. Caries Res 2008;42:394-400.

24. Deeley K, Letra A, Rose EK, Brandon CA, Resick JM, Marazita ML, Vieira AR. Possible Association of Amelogenin to High Caries Experience in a Guatemalan-Mayan Population. Caries Res 2008;42:8-13.

25. Gasse B, Grabar S, Lafont AG, Quinquis L, Opsahl Vital S, Davit-Béal T. Common Snps of Amelogeninx (AMELX) and Dental Caries 
Susceptibility. J Dent Res 2013;92:418-24.

26. Wang $X$, Willing $M C$, Marazita $M L$, Wendell $S$, Warren JJ, Broffitt B, Smith B, Busch T, Lidral AC, Levy SM. Genetic and Environmental Factors Associated with Dental Caries in Children: The Iowa Fluoride Study. Caries Res 2012;46:177-84.

27. Nikiforuk G. Understanding Dental Caries. Vol. 1: Etiology \& Mechanism. Switzerland: S. Karger AG, 1985.

28. Kang SW, Yoon I, Lee HW, Cho J. Association Between AMELX Polymorphisms and Dental Caries in Koreans. Oral Dis 2011;17:399-406.

29. Demirci F, Tanik A Güven S. Amelogenezis Imperfekta: Sınıflama, Teşhis ve Tedavi (Derleme). Atatürk Üniv Diş Hek Fak Derg J Dent Fac Atatürk Uni 2015;12:149-55.

30. Tannure PN, Küchler EC, Lips A, Costa Mde C, Luiz RR, Granjeiro JM, Vieira AR. Genetic Variation in MMP20 Contributes to Higher Caries Experience. J Dent 2012;40:381-6.

31. Çoğulu Ö, Durmaz B, Özkınay F. Genetik Hastalıklara Temel Yaklaşım. Ege Pediatri Bülteni J Pediatr Res 2006;13:57-66.

32. Buczkowska-Radlińska J, Pol J, Szmidt M, BińczakKuleta A. The Influence of Polymorphism of the MUC7 Gene on the Teeth and Dental Hygiene of Students at a Faculty of Dentistry in Poland. Postepy Hig Med Dosw 2012;66:204-9.

33. Peres RC, Camargo G, Mofatto LS, Cortellazzi KL, Santos MC, Nobre-dos-Santos M and et al. Association of Polymorphisms in the Carbonic Anhydrase 6 Gene with Salivary Buffer Capacity, Dental Plaque $\mathrm{pH}$, and Caries Index in Children Aged 7-9 Years. Pharmacogenomics J 2010;10:114-9.

34. Özata F, Demirbaş Kaya A. Diş Çürüğü ve Genetik. EÜ Dişhek Fak Derg 2001;22: 13-21.

35. Sengul F, Kilic M, Gurbuz T, Tasdemir S. Carbonic Anhydrase VI Gene Polymorphism rs2274327 Relationship Between Salivary Parameters and Dental-Oral Health Status in Children. Biochem Genet. 2016; 54:467-75.

36. Kivelä J, Parkkila S, Parkkila AK, Rajaniemi H. A Low Concentration of Carbonic Anhydrase Isoenzyme VI in Whole Saliva is Associated with Caries Prevalence. Caries Res 1999; 33:178-84.

37. Zakhary GM, Clark RM, Bidichandani SI, Owen WL, Slayton RL, Levine M. Acidic Proline-Rich Protein $\mathrm{Db}$ and Caries in Young Children J Dent Res 2007;86:1176-80.

38. Türkoğlu O, Atilla G. Ağız Boşluğunda Bir
Antimikrobiyal Peptid Ailesi: Katelisidinler. SÜ Dişhek Fak Der 2008;17:146-54.

39. Öztürk A, Famili $P$, Vieira AR. The Antimicrobial Peptide DEFB1 is Associated with Caries. J Dent Res 2010;89:631-6.

40. Özenci H. Behçet Hastaları ve Sağlıkı Kontrollerde Ağız Epitel Hücrelerinin Antibakteriyel Etkinliğinde Beta Defensinlerin (HBD-1, HBD-2 ve HBD-3) Rolünün Araştırılması. Ankara Üniversitesi Bilimsel Araştırma Projesi Kesin Raporu 2010; Proje No: $06 \mathrm{~B} 3330012$.

41. Bagherian A, Nematollahi $H$, Afshari JT, Moheghi N. Comparison of Allele Frequency for HLA-DR and HLA-DQ Between Patients with ECC and CariesFree Children. J Indian Soc Pedod Prev Dent 2008;26:18-21.

42. De Soet JJ, van Gemert-Schriks MC, Laine ML, van Amerongen WE, Morré SA, van Winkelhoff AJ. Host and Microbiological Factors Related to Dental Caries Development. Caries Res 2008; 42:340-7.

43. Pehlivan S, Koturoğlu G, Ozkinay F, Alpoz AR, Sipahi M, Pehlivan M. Might There Be a Link Between Mannosebinding Lectin Polymorphism and Dental Caries? Mol Immunol 2005;42:1125-7.

44. Bretz WA, Corby PM, Melo MR, Coelho MQ, Costa SM, Robinson M, Schork NJ, Drewnowski A, Hart TC. Heritability Estimates for Dental Caries and Sucrose Sweetness Preference. Arch Oral Biol 2006;51:1156-60.

45. Wright JT. Defining the Contribution of Genetics in the Etiology of Dental Caries. J Dent Res 2010;89:1173-4.

46. Wendell S, Wang $X$, Brown M, Cooper ME, DeSensi RS, Weyant RJ, Crout R, McNeil DW, Marazita ML.Taste Genes Associated with Dental Caries. J Dent Res 2010;89:1198-202.

47. Rupesh S, Nayak UA. Genetic Sensitivity to the Bitter Taste of 6-n Propylthiouracil: A New Risk Determinant for Dental Caries in Children. J Indian Soc Pedod Prev Dent 2006;24:63-8.

\section{Yazışma Adresi}

Gül Yıldız Telatar

Recep Tayyip Erdoğan Üniversitesi

Diş Hekimliği Fakültesi, Restoratif Diş Tedavisi

Anabilim Dalı 53000 Rize

Telefon: 05365404555

Fax: 04642220002

e-mail: gulyildiz@gmail.com 